\title{
Evaluation of Innovation Expenditures and Patents in the Polish Industry
}

\author{
JAN ZWOLAK \\ Faculty of Economies and Finance, \\ Kazimierz Pulaski University of Technology and Humanities in Radom, \\ 26-600 Radom, ul. Chrobrego 31, \\ POLAND
}

\begin{abstract}
The aim of the research has been to identify the elasticity of process and product innovation expenditures, the number of inventions as well as the number of patents in terms of net revenues generated from the sales of new and significantly improved products in the Polish industry over the years 2015-2017. Furthermore, a focus was also placed on the determination of the marginal and average productivity of innovation expenditures, as well as that of inventions and patents as observed in the Polish industry within the above-indicated period. The calculated marginal and average productivity values of independent variables allow for an indication of the areas of their rational management in the Polish industry. The research shows that the elasticity of inventions is greater (0.403) than the process and product innovation expenditures $(0.333)$. On the other hand, the second power regression performed points to the fact that the elasticity of process and product innovation expenditures is higher (0.420) than the patent expenditure $(0.251)$ within the relative increase in net revenues generated from sales of new and significantly improved products in the industry in Poland. A hypothesis has been confirmed claiming that the elasticity of patents - be it at its lowest - does increase the level of flexibility of process and product innovation expenditures in the Polish industry. A quality verification of inventions and their distinction as intellectual and legal property in the category of patents leads to the effective use of process and product innovation outlays within the relative increase in the net revenues obtained from the sale of new and significantly improved products in the industry in Poland. The conducted research reveals a new perspective on inventions and patents. Although the number of patents may show less elasticity, patents were significant in increasing the efficiency of process and product innovation expenditures effectuated within the industry in Poland over the years 2015-2017.
\end{abstract}

Key - Words: - process and product innovations, inventions, patents, regression

Received: December 19, 2019. Revised: April 7, 2020. Accepted: April 22, 2020. Published: April 30, 2020.

\section{Introduction}

The R\&D expenditure constitutes a source of obtained inventions, some of which become intellectual and legal property as the effective number of patents. A patent is a cumulative innovation, and as such, it can be used to implement technology, thus becoming a source of revenue from the sale of products or services along with process, product or service innovation expenditures. The division into process innovation and product innovation is often quite artificial (Flichy, 2007). There is a technological relationship between them (patent). The innovative process transfers innovative features (properties) onto an innovative product. In addition, patents boost the competition between enterprises (Beneito et al., 2014).

Therefore, one cannot claim that patenting is a strategic manoeuvre aimed at blocking competition. This is even more unquestionable in view of the fact that it is impossible to employ the EU innovation funds. However, the implementation of technology is only a condition for financing with $\mathrm{EU}$ funds following a pre-financing stage.

Cohen, Nelson and Walsh (2000) state that companies rarely declare patents as sources of income, seeing as not all inventions can be patented, and they do not constitute a reimbursement of costs incurred for R\&D. As pointed out by Kleinknecht et al. (2002), the following factors are no less important: human capital, intellectual capital, market assessment, marketing, commercialisation of research and others that also constitute the cost of the invention.

The reference literature on the subject presents empirical research on the effectiveness of innovation indirectly, focusing on technical innovation efficiency. Oftentimes those studies are conducted with the help of artificial variables and only in private sectors applying innovations (Fritsch and Slavtcher, 2008, Dobrzański, 2018). There are no studies based on absolute empirical variables 
relating to the economic productivity of innovation with the help of marginal and average productivity and the indication of zones of rational innovation management. This article attempts to fill this gap.

The aim of the research was to identify the elasticity of process and product innovation expenditures, followed by the number of inventions and the number of patents in relation to the net income obtained from sales of new and significantly improved products in the Polish industry in the years 2015-2017. Additionally, focus was also placed on determining the marginal and average productivity of the process and product innovation outlays, as well as that of inventions and patents, and the areas of their rational management in the Polish industry over the course of the indicated years.

The basis of the study is the hypothesis that even though the elasticity of patents may be lower, it still increases the level of elasticity of process and product innovation expenditures with a relative growth in net revenues obtained from sales of new and significantly improved products in industry in Poland.

The arrangement of this article is as follows:

- Section 2 focuses on theoretical and empirical literature,

- Section 3 describes the applied methodology,

- Section 4 contains variable parameters and their analysis,

- Section 5 presents the results and discussion,

- Section 6 contains a conclusion.

\section{Selected source literature}

Here the theory of open innovation (the business network model) presents a purposeful use of the cumulative flow of intensive knowledge exchange for the benefit of the growth of internal innovation and the creation of their external market (Gassmann et al., 2010; Hong and Doung, 2020). This exchange leads to free access to knowledge and offers up possibilities of its integration (Gassmann and Enkel, 2004). There is a positive relationship between a technological shift and employment, and this in turn stimulates new demands (Vivarelli, 2014; Marcolin et al., 2016). Technological progress allows for a transformation of innovative products and for a creative application of the work. Empirical studies do not point to a significant relationship between technological innovation (patents) and variable or, when the dependent variable is the value of production sold. It is then that patents may appear as an independent variable (a descriptive one). Kromann et al., (2011) consider R\&D expenditure unemployment (Matuzeviciute et al., 2017). Patents promote the acceleration of open innovation by means of integrating cooperation, exchange and interaction between the actors of the innovation process (Pénin and Neicu, 2018). The theory of patents indicates that patents solve two problems that are mutually exclusive: the problem of motivation to work on inventions, and the problem of the dispersion of knowledge. The latter generates the necessity to integrate knowledge in order to effectuate a growth in the number of inventions.

The number of patents is a measure of technological innovation (European Commission, 2014). It constitutes an indirect source of growth in innovative production. The patent implementation itself is a technological effect, while innovative production is an economic effect of innovation. Non-parametric methodology is a measurement technique of relative technical efficiency - it is not an absolute measure of efficiency. Technical efficiency is a proportional reduction in input use (Thanassoulis, 2001). Technical efficiency is the ratio of the biased production sum to the biased sum of inputs. This bias expresses a systematic difference between the results obtained from the study and the real state of affairs.

The patent system does not determine the absolute right to patents. It solely determines the owner of the patent, who, however, cannot be timespecific. Also, many business units focus much rather on the cost of using patents rather than their future value. The choice is related to cost necessity and its shift to the occasion of value (de Wilton, 2011). This, however, motivates the enterprise to bear the cost of innovation and leads to an increase in the standard of living (Lemley and Shapiro, 2005). The relation between $R \& D$ expenditures and the patent activity at the meso-economic level should not be taken into account, as this is an indicator of the appurtenance of the enterprise to the business sector. Therefore, a fundamental question arises: are R\&D expenses efficient and measured by a patent in the long run? Increasing patent activity of a business venture in the long-run sector depends on the management of $R \& D$ activities in entities belonging to this sector, rather than on increasing the R\&D expenditure (Sierotowicz, 2015).

Patents constitute the measure of production sold (Vivarelli, 2015; Bonanno, 2016). They may occur in the regression model as a dependent and patents to be the best variables for the assessment of changes in innovative economy. What serves as a good indicator (variable) for comparisons over time, is the number of patents per 
one million inhabitants. The correlation calculations between patent variables, production sold and the value of innovation processes show that they are identical and can be used interchangeably depending on the logic of the conducted research.

A structural shift occurs as a result of a reallocation of activities to sectors in which an intense increase in knowledge is observed. Or towards more intensive activities performed within the sector that demonstrate a greater demand for knowledge (Janger et al., 2017). In turn, technological diversity affects economic growth only in large countries (Moaniba et al., 2018). Innovations are more concentrated than inventions, which in turn show a greater density than production, measured by employment levels. Innovations are also concentrated in regions with already high production and invention levels. The significance of the concentration of innovations is reduced as the bills of the employed patents are mainly directed to patents with a high level of quality rather than to the effectiveness of $R \& D$ in a specific innovative activity (Ejermo, 2009). Recently conducted research suggests that the innovative variables adopted in this article and obtained from individual regions (administrative units) of Poland are the right choice for the study of marginal and average productivity and for the determination of rational management zones for process and product innovation outlays as well as expenditures on inventions and patents in the Polish industry.

\section{Research Methodology}

Freeman (1982), defines an innovation primarily as a commercial launch of a new product onto a market, while Mansfield (1968) defines an innovation as the first application of the invention verified by the market. Innovation as an introduction of the invention may use technology only partially (Carter and Williams, 1957). The above interpretations have not changed in modern times. Innovations are considered verified by the market inasmuch as the income (value) obtained from the sale of new and significantly improved products and services is recognised as the result of their sale and the basis for assessing marginal and average productivity generated from the innovations employed in the Polish industry.

All innovative ideas have their source in science, in the sphere of $R \& D$. According to Schumpeter's theory of innovation (1939), the development of innovation is cyclical and it is characterised by fluctuation. In a simplified way, a curvilinear model of the innovation process can be presented as follows:

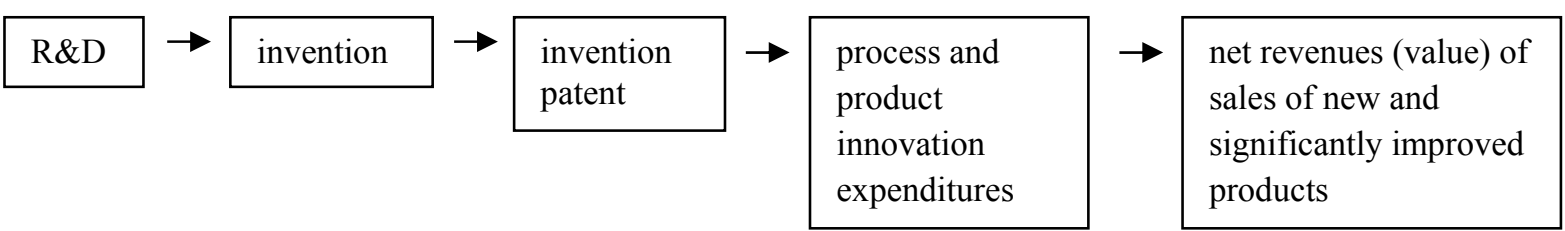

In this model two submodels can be distinguished, that of: (1) supply (Schumpeter, 1939) and (2) demand (Schmookler, 1972).

The sub-model of supply includes the following items:

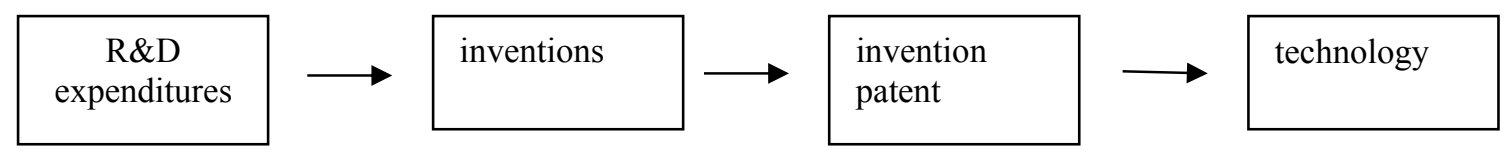

However, the demand sub-model encompasses the following items:

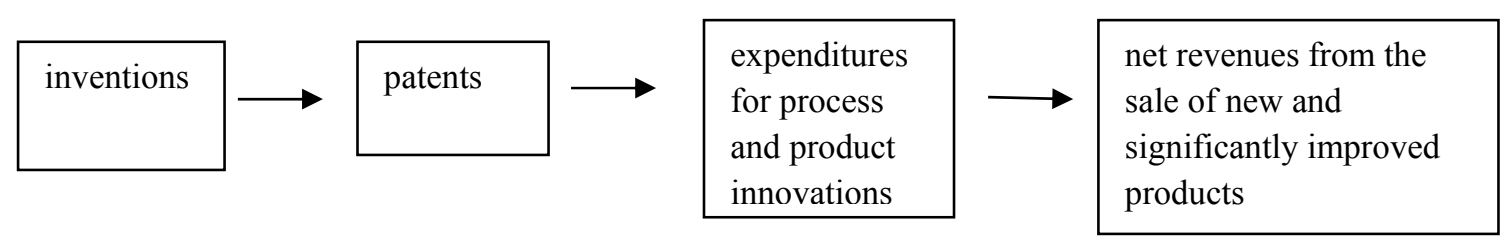


The demand concept of the innovative process (the demand submodel) is the subject of this research. These studies have been carried out with the help of the Cobb-Douglas-type curvilinear power function model. And here are the adopted variables in the model: net revenues obtained from the sale of new and significantly improved products constitute a function of expenditures for process and product innovations as well as for inventions. The second model remains the same, with the recognition of patents. The research covered industry from 16 provinces (administrative units in Poland) between the years 2015 - 2017, whereby N $=28$. The research is of macroeconomic nature.

In the industry in Poland, only about $20 \%$ of enterprises run R\&D activities. This, however, does not mean that only about one-fifth of enterprises within this industry have new and significantly improved products. Most of them use existing inventions and patents. Therefore, the R\&D measure cannot be used as the one that indicates the number of innovative enterprises within the Polish industry.

The distribution of the random component was examined using a graphical analysis and a series number test, with a significance level of 0.05 . Both the graphical analysis - as well as the series number test - confirm the hypothesis about the correct selection of the function model (Table 2). The normality of the random component was examined by means of the Kolomogorov-Liliefors test. The calculated values, when compared to the critical ones with the significance of 0.05 , do not defy the hypothesis that there is a normal distribution of random components. The autocorrelation was tested using the Durbin-Watson test and the lack of autocorrelation of the random component was found, with the significance level of 0.05 . The hypothesis of homoscedasticity of random components was verified using the Godfeld-Quandt test. At the significance of 0.05 , the recorded critical values of $F$ Snedecor's distribution are higher than those calculated, which indicates that there are no grounds for rejecting the hypothesis of homoscedasticity of random components.

\section{Data and Empirical Analysis}

The empirical sets of the innovative industry in all voivodeships in Poland in the years $2015-2017$ $(\mathrm{N}=48)$ are the subject of the study (Table 1).

Table 1: Parameters of variables in different voivodeships within the Polish industry in the years 2015-2017

\begin{tabular}{|c|c|c|c|c|c|c|}
\hline Item & Specification & Symbol & $\begin{array}{l}\text { Measuring } \\
\text { Unit }\end{array}$ & $\begin{array}{l}\text { Arithmetic } \\
\text { average }\end{array}$ & $\begin{array}{l}\text { min. - max. } \\
\text { range }\end{array}$ & $\begin{array}{l}\text { Coefficient } \\
\text { of variation }\end{array}$ \\
\hline 1. & $\begin{array}{l}\text { Net revenues from sales } \\
\text { of new and significantly } \\
\text { improved products }\end{array}$ & Y1 & $\begin{array}{l}\text { MM (mil) } \\
\text { PLN }\end{array}$ & 640.9 & $212.3-1453.5$ & 62.8 \\
\hline 2. & $\begin{array}{l}\text { Process and product } \\
\text { innovation expenditures }\end{array}$ & $\mathrm{X} 1$ & $\begin{array}{l}\text { MM (mil) } \\
\text { PLN }\end{array}$ & 1496.7 & $251.6-4944.5$ & 84.7 \\
\hline 3. & $\begin{array}{l}\text { Number of inventions in } \\
\text { industry }\end{array}$ & $\mathrm{X} 2$ & number & 267.9 & $59.0-983.0$ & 78.8 \\
\hline 4. & $\begin{array}{l}\text { Number of patents in } \\
\text { industry }\end{array}$ & $\mathrm{X} 3$ & number & 177.3 & $21.0-811.0$ & 93.3 \\
\hline
\end{tabular}

Source: Statistical voivodeship yearbook of 2015, 2016 and 2017. Central Statistical Office in Warsaw, years 2016, 2017 and 2018. Calculations by the Author.

The lowest internal variability (dispersion) is shown by the set of net revenues obtained from sales of new and significantly improved products in Poland (Table 1). The average, on the other hand, describes collectively all the values of the set, and it is nearly 2.3 times lower than the maximum value of the set.

It should be also noted that this is a net value adjusted to reflect the due subsidies, as well as rebates and discounts granted. It is also 1.3 times lower than the number of the centre of the set range $\left(0,5\left(x_{n}+x_{1}\right)\right)$.

The internal variability of process and product innovation expenditures is higher by almost 22 percentage points $(84.7 \%)$. And their average value in relation to the maximum value within the set is 3.3 times lower, and it is 1.7 times smaller in relation to the number of the middle range of the set.

In contrast, the number of inventions generated in industry in the studied period shows a greater internal variation by 16 percentage points as compared to net revenues obtained from sales of 
new and significantly improved products. The average number of inventions is 3.7 times lower than the maximum value in the set, and it is over 1.9 times smaller than the centre number of the set range.

The highest internal variability within the set in the analysed years is demonstrated by patents. Their variability is higher by more than 30 percentage points in relation to the internal variability of the net revenues generated from sales of new and significantly improved products in the studied period. The patent average is nearly 4.6 times lower than their maximum characteristic in the set, and 2.3 times lower than the number in the centre of the set range.

In all sets of variables, according to the chronology of their inclusion in Table 1, the decrease in averages is growing, which is half of the decrease in relation to the centre number of the range of each set. Thus, there is a causal relationship between the highest value of the characteristic of each set and the centre numbers of the ranges in each of the sets. This relationship is the same in all sets of variables encompassed by the study.

\section{Results and Discussion}

The demand model (submodel), which has its source in the needs of customers, owing to whom the industry receives net revenues from the sale of new and significantly improved products, was expressed by the Cobb-Douglas curvilinear power regression. It was included in the tabular convention, in two models, and presented in Table 2.

Table 2: Power regressions of net revenues generated from sales of new and significantly improved products (Y1) from process and product innovation expenditures (X1) and number of inventions (X2), and in the second model alike, from process and product innovation expenditures (X1) and number of patents (X3) generated within industry in Poland in years 2015 - 2017.

\begin{tabular}{|c|c|c|c|c|c|c|c|c|c|}
\hline \multirow[t]{2}{*}{$\mathrm{a}$} & \multicolumn{2}{|c|}{$\begin{array}{l}\text { Regression } \\
\text { coefficient } \\
\text { (parameter) }\end{array}$} & \multicolumn{3}{|c|}{ Standard error } & \multicolumn{3}{|c|}{ T Test } & $\begin{array}{r}\mathrm{R}^{2} \\
\text { adjusted }\end{array}$ \\
\hline & $\mathrm{X} 1$ & $\mathrm{X} 2$ & $\mathrm{a}$ & $\mathrm{X} 1$ & $\mathrm{X} 2$ & $\mathrm{a}$ & $\mathrm{X} 1$ & $\mathrm{X} 2$ & 0.85 \\
\hline $\begin{array}{l}1.804 \\
6.0739^{*}\end{array}$ & 0.333 & 0.403 & 0.29 & 0.09 & 0.11 & 6.3 & 3.7 & 3.7 & \\
\hline & $\mathrm{X} 1$ & X3 & $\mathrm{a}$ & $\mathrm{X} 1$ & $\mathrm{X} 3$ & $\mathrm{a}$ & $\mathrm{X} 1$ & X3 & 0.85 \\
\hline $\begin{array}{l}2.141 \\
8.5079^{*}\end{array}$ & 0.420 & 0.251 & 0.30 & 0.07 & 0.07 & 7.1 & 5.8 & 3.6 & \\
\hline
\end{tabular}

Source: as in Table 1. Author's own calculations.

$\mathrm{a}^{*}$ - delogarithmised;

The level of significance of all parameters in the range: $0.00-0.00$.

The data contained in Table 2 present a regressive dependence of net revenues obtained from sales of new and significantly improved products (Y1) from process and product innovation expenditures (X1) and the number of inventions (X2), and in the second model - that of patents (X3) generated within the Polish industry in the years 2015-1017. In both models, the variability of net revenues obtained from sales of new and significantly improved products is explained by the process and product innovation outlays and the number of inventions and the number of patents (in the second model) generated within industry in $85 \%$. A very good explanation there for has been obtained. The unexplained variability is implemented by other variables that are not subject to the study. The multiple correlation coefficient
(R), which measures the strength of the relationship between variables, is $92 \%$ in both regression models. Regression coefficients (parameters) contain standard errors lower than $50 \%$ of their absolute values. On the other hand, the values of the $t$ test are several times higher than the absolute values of the regression coefficients, and the significance level of regression coefficients in both models ranges from 0.00 to 0.00 . The indicated statistical estimates of the regression coefficients explain that there is the possibility of their use in the econometric analysis of the variability of net revenues obtained from sales of new and significantly improved products in industry in Poland in the years 2015-2017.

The regression coefficients (parameters) at X1 and $\mathrm{X} 2$ as well as $\mathrm{X} 1$ and $\mathrm{X} 3$ determine the 
elasticity of net revenues generated from the sale of new and significantly improved products against the process and product innovation outlays and the number of inventions and the number of patents (second model) generated in industry in the years 2015-2017, hence they are referred to as the elasticity coefficients. The elasticity coefficient indicates the average percentage (increases or decreases) of the dependent variable (Y1), whereby factor $\mathrm{Xj}$ is increasing by $1 \%$, while the remaining factors remain constant.

The flexibility of net revenues obtained from the sale of new and significantly improved products (Table 2) is higher in relation to the number of inventions (0.403) than the process and product innovation expenditures (0.333). In the second model it is higher in relation to the process and product innovation outlays $(0.420)$ than to the number of patents $(0.251)$. The relationship of elasticity coefficients (regression) shows that net revenues obtained from the sales of new and significantly improved products in relation to the number of inventions are 1.2 times higher than in relation to process and product innovation expenditures. In the second model, on the other hand, in relation to the process and product innovation expenditures, it is 1.67 times higher than in relation to the number of patents generated. The comparison of the sum of elasticity from both models shows that in the first model it is higher by $0.8 \%$. The relative comparisons of elasticity show that the number of patents significantly increases the elasticity of net revenues obtained from sales of new and significantly improved products, as compared to the process and product innovation expenditures implemented in the Polish industry in the years 2015-2017.

The total increase in process and product innovation expenditures and the number of inventions by $10 \%$ results in an increase in net revenues obtained from sales of new and significantly improved products by $7.36 \%$.
Similarly, the total increase in process and product innovation expenditures and in the number of patents by $10 \%$ results in an increase in net revenues generated from sales of new and significantly improved products by $6.71 \%$. The advantage of these products is a relatively constant marginal utility, while their markets are not limited by the level of saturation. It is therefore possible to use economies of scale, thus reducing the production costs.

Where the elasticity amount $=100 \%$, the impact of process and product innovation expenditures on the relative increase in net revenues from sales of new and significantly improved products equals $45.2 \%$, while that of the number of inventions is $54.8 \%$. In turn, the asymmetry of influence occurs in the second model, where the impact of process and product innovation expenditures on the relative increase in net revenues obtained from sales of new and significantly improved products within industry in the analysed years amounts to $62.6 \%$, and that of the number of patents to $37.4 \%$. The successful protection of the invention from getting copied by third parties and the increase in the anticipated useful life of the technology are important features of the implementation of patents, also characterising the increase in the use of process and product innovation expenditures within industry.

The classic Cobb-Douglas form regression allows for a determination of the marginal and average productivity of the process and product innovation outlays as well as those of inventions and patents. On the other hand, the nature of changes in marginal and average productivity of the abovementioned independent variables renders it possible to indicate the areas of their rational management over the analysed period.

The marginal and average productivity of process and product innovation expenditures implemented in the Polish industry has been shown in Table 3.

Table 3: Marginal and average productivity of process and product innovation expenditures implemented in the Polish industry in the years 2015-2017.

\begin{tabular}{|c|c|c|c|}
\hline \multirow{2}{*}{$\begin{array}{l}\text { Net revenues obtained from sales of } \\
\text { new and significantly improved } \\
\text { products (Y1) million PLN }\end{array}$} & \multirow{2}{*}{$\begin{array}{l}\text { Process and product } \\
\text { innovation expenditures (X1) } \\
\text { million PLN }\end{array}$} & \multicolumn{2}{|c|}{ Productivity: } \\
\hline & & $\begin{array}{l}\text { average } \\
\text { PLN/PLN }\end{array}$ & $\begin{array}{l}\text { marginal } \\
\text { PLN/PLN }\end{array}$ \\
\hline 506.81 & 678.20 & 0.7473 & 0.2488 \\
\hline 596.24 & 1104.80 & 0.5397 & 0.1797 \\
\hline 664.72 & 1531.40 & 0.4341 & 0.1445 \\
\hline 721.41 & 1958.00 & 0.3684 & 0.1227 \\
\hline
\end{tabular}




\begin{tabular}{|l|l|l|l|}
\hline 770.35 & 2384.60 & 0.3231 & 0.1076 \\
\hline 813.74 & 2811.20 & 0.2895 & 0.0964 \\
\hline 852.94 & 3237.80 & 0.2634 & 0.0877 \\
\hline 888.83 & 3664.40 & 0.2426 & 0.0808 \\
\hline 922.03 & 4091.00 & 0.2254 & 0.0751 \\
\hline 952.99 & 4517.60 & 0.2110 & 0.0702 \\
\hline
\end{tabular}

Source: Author's own calculations based on data from Tables 1 and 2.

The data in Table 3 show that the marginal productivity of process and product innovation expenditures decreases and is infinitesimal, which results in a decrease in the average productivity of these outlays, but at a slow pace. The marginal and average productivity of the researched expenditures limits the growth of global productivity (it has not been included), which is infinitesimal. The character of the above changes in marginal and average productivity of process and product innovation expenditures explains the fact that they were used in the rational industry management zone over the analysed period.

Data in Table 4 show that process and product innovation expenditures (second regression) have a higher marginal and average productivity at the same levels, while the nature of the shifts occurred is the same as that presented in Table 3. Similarly to the data included in Table 3, process and product innovation expenditures were used in the rational management zone. The delineated limiting conditions - which are the same in Tables 3 and $4-$ of the process and product innovation outlay delineate the area of acceptable solutions, among which the optimal solution (the best one) is found. Patents coexisting in a relationship with the process and product outlays support a higher level of marginal and average productivity of these expenditures in the Polish industry.

Table 4: Marginal and average productivity of process and product innovation expenditures implemented in the industry in Poland in the years 2015-2017 (second regression).

\begin{tabular}{|c|c|c|c|}
\hline \multirow{2}{*}{$\begin{array}{l}\text { Net revenues obtained from sales of } \\
\text { new and significantly improved } \\
\text { products (Y1) million PLN }\end{array}$} & \multirow{2}{*}{$\begin{array}{c}\text { Process and product } \\
\text { innovation expenditures (X1) } \\
\text { million PLN }\end{array}$} & \multicolumn{2}{|c|}{ Productivity: } \\
\hline & & $\begin{array}{l}\text { average } \\
\text { PLN/PLN }\end{array}$ & $\begin{array}{l}\text { marginal } \\
\text { PLN/PLN }\end{array}$ \\
\hline 482.21 & 678.20 & 0.7110 & 0.2986 \\
\hline 591.89 & 1104.80 & 0.5357 & 0.2250 \\
\hline 678.89 & 1531.40 & 0.4433 & 0.1862 \\
\hline 752.71 & 1958.00 & 0.3844 & 0.1615 \\
\hline 817.67 & 2384.60 & 0.3429 & 0.1440 \\
\hline 876.19 & 2811.20 & 0.3117 & 0.1309 \\
\hline 929.76 & 3237.80 & 0.2872 & 0.1206 \\
\hline 979.37 & 3664.40 & 0.2673 & 0.1123 \\
\hline 1025.73 & 4091.00 & 0.2507 & 0.1053 \\
\hline 1069.36 & 4517.60 & 0.2367 & 0.0994 \\
\hline
\end{tabular}

Source: Author's own calculations based on data from Tables 1 and 2.

The data from table 5 show that the marginal productivity of inventions decreases towards zero, also causing their average productivity to decrease at the same rate $(-11.48 \%)$, while global productivity (it has not been included therein), although it is growing, it is increasing at a pace of regression and it is infinitesimal. The nature of these changes corresponds to the zone of rational management of inventions in the Polish industry.

Table 5: Marginal and average productivity of inventions in industry in Poland in the years 2015-2017.
\begin{tabular}{|r|r|r|r|}
\hline Net revenues obtained from sales & Number of inventions
\end{tabular} of new and significantly improved generated within the industry \begin{tabular}{l|l} 
(X2) number & PLN/number
\end{tabular} Productivity: products (Y1) million PLN PLN/number 


\begin{tabular}{|l|l|l|l|}
\hline 512.14 & 143.00 & 3.5814 & 1.4433 \\
\hline 616.97 & 227.00 & 2.7179 & 1.0953 \\
\hline 700.44 & 311.00 & 2.2522 & 0.9076 \\
\hline 771.29 & 395.00 & 1.9526 & 0.7869 \\
\hline 833.61 & 479.00 & 1.7403 & 0.7013 \\
\hline 889.70 & 563.00 & 1.5803 & 0.6369 \\
\hline 940.98 & 647.00 & 1.4544 & 0.5861 \\
\hline 988.43 & 731.00 & 1.3522 & 0.5449 \\
\hline 1032.72 & 815.00 & 1.2671 & 0.5107 \\
\hline 1074.37 & 899.00 & 1.1951 & 0.4816 \\
\hline
\end{tabular}

Source: Author's own calculations based on data from Tables 1 and 2.

Based on the number of the centre of the set range $\left(0,5\left(\mathrm{X}_{\mathrm{n}}+\mathrm{X}_{1}\right)\right)$ of marginal productivity $(0.9624)$ and average productivity (2.3883) of inventions, it can be indicated that the ratio of these efficiency categories is as follows: 1: 2.5 . The centre number of the set range of the marginal productivity of inventions is 2.5 times lower than the number of the centre of the range of average productivity of inventions generated in industry in Poland.

Table 6: Marginal and average productivity of patents generated in the Polish industry in the years 2015-2017.

\begin{tabular}{|c|c|c|c|}
\hline \multirow{2}{*}{$\begin{array}{l}\text { Net revenues obtained from sales of } \\
\text { new and significantly improved } \\
\text { products (Y1) million PLN }\end{array}$} & $\begin{array}{c}\text { Number of patents } \\
\text { generated within the industry } \\
\text { (X2) number }\end{array}$ & $\begin{array}{c}|c| \\
\text { average } \\
\text { PLN/number }\end{array}$ & $\begin{array}{c}\text { marginal } \\
\text { PLN/number }\end{array}$ \\
\hline 572.10 & 93.00 & 6.1516 & 1.5440 \\
\hline 660.64 & 165.00 & 4.0039 & 1.0050 \\
\hline 723.50 & 237.00 & 3.0528 & 0.7662 \\
\hline 773.32 & 309.00 & 2.5026 & 0.6282 \\
\hline 815.06 & 381.00 & 2.1393 & 0.5370 \\
\hline 851.25 & 453.00 & 1.8791 & 0.4717 \\
\hline 883.36 & 525.00 & 1.6826 & 0.4223 \\
\hline 912.32 & 597.00 & 1.5282 & 0.3836 \\
\hline 938.77 & 669.00 & 1.4032 & 0.3522 \\
\hline 963.17 & 741.00 & 1.2998 & 0.3263 \\
\hline
\end{tabular}

Source: Author's own calculations based on data from Tables 1 and 2.

The data presented in Table 6 show that the level of productivity of marginal patents is lower than the productivity of marginal inventions (Table 5), while the level of average productivity of patents is in turn higher than the average productivity of inventions generated in industry over the analysed years.

The nature of the changes (as is also the case with the data shown in Table 5), also in the case of patents, corresponds to the area of their rational management in the Polish industry.

Table 7: Average growth rate of net revenues obtained from sales of new and significantly improved products (Y1) within the scope of process and product innovation expenditures (X1) as well as that of inventions (X2) and patents (X3) generated within the Polish industry in the years 2015-2017,\%.

\begin{tabular}{|l|c|c|c|c|}
\hline Specification & Table 3 & Table 4 & Table 5 & Table 6 \\
\hline $\begin{array}{l}\text { Sales value of new and significantly improved } \\
\text { products (Y1) }\end{array}$ & 7.27 & 9.25 & 8.58 & 5.96 \\
\hline $\begin{array}{l}\text { Process and product innovation expenditures } \\
\text { (X1) }\end{array}$ & 23.45 & 23.45 & & \\
\hline
\end{tabular}




\begin{tabular}{|l|l|l|l|l|}
\hline Number of inventions in industry (X2) & & & 22.60 & \\
\hline Number of patents in industry (X3) & & & & 25.94 \\
\hline $\begin{array}{l}\text { Marginal productivity of process and product } \\
\text { innovation expenditures }\end{array}$ & -13.11 & -11.50 & & \\
\hline $\begin{array}{l}\text { Average productivity of process and product } \\
\text { innovation expenditures }\end{array}$ & -13.11 & -11.50 & & \\
\hline Marginal productivity of inventions & & & -11.48 & \\
\hline Average productivity of inventions & & & -11.48 & \\
\hline Marginal productivity of patents & & & & -15.86 \\
\hline Average productivity of patents & & & & -15.86 \\
\hline
\end{tabular}

Source: Author's own calculations based on the data from Tables 3, 4, 5 and 6, obtained by means of dynamics based on the variable and the geometric mean.

With the help of the centre range of the set of marginal $(0.9352)$ and average productivity $(3,726)$ of patents, it can be stated that the ratio of these efficiency categories is as follows: 1: 4. This, in turn, means that the middle of the range of the set of average patent productivity is 4 times larger than the middle of the range of the marginal productivity set for the Polish industry.

The centre of the range of the set of marginal productivity of inventions and patents is similar, and that of the average productivity of patents is 1.5 times higher than that of the average productivity of inventions as observed in the industry in Poland.

The data presented in Table 7 show that process and product innovation expenditures are increasing at the same average growth rate within their range of variability $(23.45 \%)$. On the other hand, net revenues generated from the sale of new and significantly improved products increase faster at an average growth rate within their range by 2 percentage points, when process and product innovation expenditure is boosted by the number of patents at the average growth rate within their range by 3.34 percentage points more than the number of inventions within their range in the industry. Marginal and average productivity of process and product innovation expenditures, as well as that of the number of inventions and patents, each within their range, are the same and have a negative average growth rate in industry over the analysed period.

\section{Conclusions}

It has been possible to successfully confirm the hypothesis that the elasticity of patents, although it may be lower, still increases the elasticity level of process and product innovation expenditures with the relative increase in net revenues obtained from sales of new and significantly improved products in the Polish industry in the years 2015-2017. Quality verification of inventions and their distinction in the patent category leads to an efficient application of process and product innovation expenditures with the relative increase in net revenues generated from sales of new and significantly improved products in the industry in Poland over the period 2015-2017.

Research shows that the elasticity of inventions is greater $(0.403)$ than that of process and product innovation expenditures ( 0.333$)$. On the other hand, the second power regression indicates that the elasticity of process and product innovation expenditures is higher $(0.420)$ than that of patents $(0.251)$ with the relative increase in net revenues obtained from sales of new and significantly improved products in the Polish industry. Marginal productivity of process and product innovation expenditures, as well as that of the number of inventions and the number of patents is infinitesimal, which results in a decrease in the average productivity of these variables, albeit at a slow pace. The nature of the above-specified changes in marginal and average productivity of process and product innovation expenditures, as well as that of the number of inventions and the number of patents explains that they were used in the rational industry management zone in Poland over the course of the period studied.

The range centre of the set of marginal productivity of inventions and patents is similar, and that of the average productivity of patents is 1.5 times higher than that of the average productivity of inventions within the Polish industry. The conducted research reveals a new perspective on inventions and patents. Although the elasticity of patents may be lower, they are still valuable in the increase in productivity of process and product innovation expenditures and that of the patents themselves, as observed in industry in Poland over the analysed period. 
The Cobb-Douglas power regression model used in the study facilitates an analysis of variables with different titers and the identification of their impact on the relative increment of the dependent variable.

The settlement of influence of expenditures more far investigations be become consecrated and technology innowacyjnech on different results.

\section{References}

[1] Beneito, P., Rochina-Barrachina, M. E., and Sanchis, A. Patents, competition, and firms' innovation incentives, Industry and Innovation, Vol. 21, No. 4, 2014, pp. 285-309,

[2] Bonanno, G. ICT and R\&D as inputs or efficiency determinants? Analysing Italian manufacturing firms (2007-2009), Eurasian Business Review, Vol. 6, No. 3, 2016, pp. 383404,

[3] Carter, C.F., and Williams, B.R. Industry and Technical Progress, Oxford University Press, Oxford, 1957.

[4] Cohen, W.M., Nelson, R., and Walsh, J.P. Protecting Their Intellectual Assets: Appropriability Conditions and Why U.S. Manufacturing Firms Patent (or Not), No 7552, NBER Working Papers, National Bureau of Economic, 2000, Research, Inc, doi: $10.3386 / w 7552$.

[5] de Wilton, A. Patent Value: A Business Perspective for Technology Startups, Technology Innovation Management Review, Vol. 1, No. 3, 2011, pp. 5-11.

[6] Dobrzanski, P. Innovation expenditures efficiency in Central and Eastern European Countries, Zbornik radova Ekonomskog fakulteta u Rijeci. Vol. 36, No. 2, 2018, pp. 827-859.

[7] Ejermo O. Regional Innovation Measured by Patent Data-Does Quality Matter?, Industry \& Innovation, Vol. 16, No. 2, 2009, pp. 141-165.

[8] European Comission, Europe 2020: Europe growth strategy: growing to a sustainable and Job-rich future, Luxembourg: Publications Office of the European Union, 2014, ISBN 978-92-79-41438-1.

[9] Feldmann, H. Technological unemployment in industrial countries, Journal of Evolutionary Economics, Vol. 23, No. 5, 2013, pp. 10991126.

[10] Flichy, P. 2007 The internet imaginaire. MIT press.
[11]_Freeman, Ch. 1982 The Economics of Industrial Innovation, Pinter, London.

[12] Fritsch, M., Slavtchev, V. Determinants of the efficiency of regional innovation systems, Regional Studies, Vol. 45, No. 7, 2008, pp. 905-918,

[13] Gassmann, O., and _Enkel, E., Towards a Theory of Open Innovation: Three Core Process Archetypes. - R\&D Management Conference (RADMA) 2004. - Lissabon.

[14] Gassmann, O., Enkel, E., and Chesbrough, H. The future of open innovation, $R \& D$ Management, Vol. 40, No. 3, 2010, pp. 213221.

[15] Hong, N.T.P., Doung L.N.K. Effects of Earnings Management to Investor Decision Empirical Evidence in Vietnam Stock Market, WSEAS Transactions on Environment and Development, Vol. 16, 2020, pp. 84-97.

[16] Janger, J., Schubert, T., Andries, P., Rammer, C., and Hoskens, M. The EU 2020 innovation indicator: A step forward in measuring innovation outputs and outcomes?, Research Policy, Vol. 46, No.1, 2017, pp. 30-42.

[17] Kleinknecht, A., Van Montfort, K. and Brouwer, E. The Non-Trivial Choice between Innovation Indicators, Economics of Innovation and New Technology, Vol. 11, No. 2, 2002, pp. 109-121.

[18] Kromann, L., Skaksen, J.R., and Sorensen, A. 2011, Automation, Labour Productivity and Employment-A Cross Country Comparison. Working Paper, CEBR, Copenhagen Business School, Copenhagen.

[19] Lemley, M.A., and Shapiro, O. Probabilistic Patents, Journal of Economic Perspectives, Vol. 19, No. 2, Spring 2005, 2005. pp. 75-98.

[20] Mansfield, E. 1968, Industrial Research and Technological Innovation: An Econometric Analysis, Norton and Co., New York, NY, USA.

[21] Marcolin, L., and Miroudot, S., M. Squicciarini (2016) Routinejobs, employment and technological innovation in global valuechains" OECD Science, Technology and Industry WorkingPapers, 2016/01, OECD Publishing, Paris.

[22] Matuzeviciute, K., Butkus, M., and Karaliute, A. Do Technological Innovations Affect Unemployment? Some Empirical Evidence from European Countries, Economies,Vol. 48, No 5, 2017, pp. 1-19,

[23] Moaniba, I. M., Su, H.-N., and Lee, P.-C. Does reverse causality explains the relationship 
between economic performance and technological diversity?, Technological and Economic Development of Economy, Vol. 24, No. 3, 2018, pp. 859-892.

[24] Pénin, J., and Neicu, D. Patents and Open Innovation: Bad Fences Do Not Make Good Neighbors, Journal of Innovation Economics \& Management 2018/1, No. 25, 2018, pp. 57-85,

[25] Schmookler J. 1972, Patens Invention and Economic Change, Harvard University Press, Cambridge.

[26] Schumpeter, J. A. 1939, Business Cycles: A Theoretical, Historical, and Statistical Analysis of the Capitalist Process, New York and London, McGraw - Hill Book Company Inc.

[27] Sierotowicz, T. Patent activity as an eff ect of the research and development of the business enterprise sectors in the countries of the European Union, Journal of International Studies, Vol. 8, No 2, 2015, pp. 101-113.

[28] Thanassoulis, E. 2001, Using Data Envelopment Analysis in Practice, In: Introduction to the Theory and Application of Data Envelopment Analysis, pp. 89-121, Springer, Boston, MA.

[29] Vivarelli, M. 2015, Innovation and employment. IZA World of Labor, 154, doi: 10.15185/izawol.154.

[30] Vivarelli, M. Innovation, Employment and Skills in Advanced and Developing Countries: A Survey of Economic Literature. Journal of Economic Issues, Vol. 48, No. 1, 2014, pp. 123-154. 